\title{
Behavior of School Leadership in Improving the Quality of Education at SD Negeri II Kayuagung Sub- District Ogan Komering Ilir District
}

\author{
Betty Yulia ${ }^{1 *}$, Bukman Lian ${ }^{2}$, Syaiful Eddy ${ }^{2}$

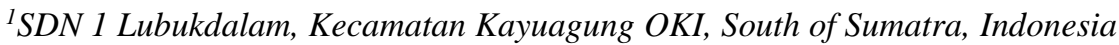 \\ ${ }^{2}$ Universitas PGRI Palembang, Indonesia \\ *Corresponding author. Email: raden.betty1977@gmail.com
}

\begin{abstract}
The goal of this study is to evaluate the leadership conduct of school principals in improving the quality of SDN II, Kayuagung District, Ogan Komering Ilir District, on the basis of the problems and objectives of this study, using a qualitative analysis approach using a descriptive framework, the topic of this study is SDN 2 Kayuagung, SDN 1 Muarabaru, SDN 16 Kayuagung, SDN 1 Tanjungrancing, with a total of 4 school principals, 57 education staff, 4 administrators and 4 school boards. The methods used to collect data were observation and questionnaire techniques. The leadership style used is the same from the outcomes of interviews with the Principal, Educational Staff, Administration and School Committee. The curriculum used from 2015-2016, i.e. KTSP, modified the curriculum in 2017-2020 according to the relevant PERMEN using K13. The job status of the workers is $99.20 \%$ civil servants, honor $0.8 \%$. The state of the workforce on the basis of the data collected is $100 \%$ eligible for Strata $1 / \mathrm{S} 1$, the national standard school exam scores are raised by $25 \%$ per year and the number of graduates is $100 \%$ per year. The condition of the facilities and infrastructure in the SDN II of the Kayuangung District is incomplete and there are still items that need to be strengthened gradually, the achievements achieved are also well recorded every year in the SDN cluster II of the Kayuagung District, which scores various competitions/competitions at the sub-district level, the district level and at the national level.
\end{abstract}

Keywords: Principal Behavior, School Facilities and Infrastructure, Education Personnel

\section{INTRODUCTION}

Education is an important factor for further study, since education is structured in order to grow the ability of students to become human beings who believe and fear God the Almighty, have a noble character, are safe, intelligent, imaginative, autonomous, and become democratic people. As well as being responsible for the goals of education. Education is a very important human need, because education has a responsibility to prepare human capital for the growth and advancement of the country [1]

In line with the complexities of global life, education plays a strategic role in advanced times, and the excellence of a nation no longer depends on natural capital, but on the advantages of human resources. Quality human resources can be realized through a successful educational mechanism and through quality educational institutions [2];[3]. The quality of human resources is dictated by the quality of education, the quality of education metrics is based on the conditions of production and the outcome that meet the requirements to meet the demands of the times. Quality education is capable of developing positive potentials that are concealed within students [4]. In order to realize the standard of education, an acceptable aspect of education must be funded. These components become inputs to be processed in such a way as to achieve superior outputs and outputs [5].

Education as a human right for every individual child of the nation has been recognized in Article 31(1) of the Constitution of 1945 , which provides that every person has the right to education, while paragraph (3) also provides that the government seeks and implements a national education system that increases confidence. And devotion and noble character within the context of the intellectual life of the nation as governed by law. Therefore, all members of the country, including parents, society and the government, are responsible for educating the nation through education. This is one of 
the purposes of the Indonesian nation required by the Preamble to the Constitution of 1945, paragraph 4.

The status of the educational institutions (schools) in our country today still has some classical problems, namely the lack of school facilities, the condition of the buildings that have been destroyed, the standard of the teaching staff has not met the competence and the policies are less effective. On the other hand, it is very promising that there is a rising public understanding of the value of quality education.

The success of a school is a school with successful leaders. "Leadership is one of the dimensions of competence that is crucial to the performance or success of an organization" Sudarmanto [6] said. The achievement of the standard and goals of education is highly dependent on the expertise and wisdom of the principal as a leader in education.

Wahjosumidjo [7] said, "School leaders are those who are described as people who have high expectations of staff and students, school leaders are those who know a lot about tasks." This statement demonstrates how important the standard of the principal's leadership is to the success of the school.

The standard of education would be of high quality if it is accompanied by an acceptable aspect of education. These components become data (input) to be processed in such a way as to achieve superior output and impact. Improving the standard of education (schools) is not easy, achieving good quality is not necessarily associated with the amount of money spent, the location of a school in a village or town, state or private, but is very much determined by how the school offers quality services to students in order to produce quality students. Modern schooling carries the fate of accountability for destructive developments in the moral and spiritual domain of humanity [8].

According to Cepi Triana [9], the standard of education is the happiness of educational service users. In the context of education, quality description refers to input, method, output and effect. The consistency of the feedback can be seen from a variety of sides. First, whether or not the feedback of human resources is strong, such as school principals, teachers, staff or administration, and students. Second, whether or not the content input requirements are met in the form of props, books, curriculum, school infrastructure, services, and so on. Third, whether or not the input requirements in the form of software are met, such as laws, organizational structure, work descriptions. Fourthly, the standard of feedback in the form of aspirations and needs, such as vision, inspiration, persistence and ideals.

According to Mulyasa [5], "professional school principals in the new paradigm of education management will have a positive impact and a fairly basic change in reforming the education system in schools" These impacts include, but are not limited to, the quality of education, good school leadership, efficient management of education staff, quality culture, lightweight, intelligent and dynamic teamwork, freedom, engagement of school and community members, openness of management, willingness to change (psychological and physical). Continuous assessment and change, sensitive and anticipatory to needs, transparency and sustainability.

In general, it can be assumed that the standard of education can be reached if all components of education comply with the requirements. The principal is one of several elements of education. Principals that excel because they recognize the nature of the school as a dynamic and specific entity and are willing to perform the position of principal as someone who has the responsibility to lead the school. Key performance studies indicate that the principal is someone who decides the center point and rhythm of the school. There are two essential things in this formula, namely (1) the theory as a central force that becomes the driving force of school life; (2) for the success of the school, the principals must recognize their roles and functions as a condition of care for staff and students.

The theory is one of the components of education that plays the most part in enhancing the standard of education. As specified in Article 12(1) PP 28 of 1990 [10]: 'The principal shall be responsible for the execution of educational programs, the administration of schools, the coaching of other educational staff and the use and maintenance of facilities and infrastructure.' Government Regulation No 19 Year 2005 on National Education Standards of 16 May 2005 Article 38 paragraph 2 reads: 'The requirements for being an SD/MI principal include: (a) SD/MI teacher status; (b) Academic credentials and integrity as a learning agent in compliance with relevant laws and regulations; (c) teaching experience in SD/MI for at least 5 (five) years; and (d) leadership and entrepreneurial skills in the field of education. 'As well as the Regulation of the Minister of National Education Number: 13 of 2007 of 17 April 2007 concerning the Requirements for Schools/Madrasah Principals, Article 1 paragraph reads: 'In order to be named principal of a school/Madrasah, a person must comply with the standards of the school/Madrasah Principal which apply nationally'.

The emphasis of this study is "Principal Leadership Actions in Improving Education Quality in Elementary School Cluster II, Kayuagung District, Ogan Komering Ilir District: SDN 2 Kayuagung, SD N 1 Muara Baru, SDN 16 Kayuagung and SDN 1 Tanjungrancing. As for the author's interest in choosing this school, SD N 2 Kayuangung is located closer to SDN 1 Muarabaru. SDN 16 Kayuagung and SDN 1 Tanjungrancing located near to each other, SDN 16 kayuangung, students are few but have a lot of success while SDN 1 
Tanjungrancing has few students and their achievements are poor. Research-based questions were formulated as follows: How are the types, roles, help and inhibiting factors of primary leadership in improving the quality of education as well as the reality of the quality of SDN education in Cluster II Elementary Schools, Kayuagung District, Ogan Komering Ilir Regency? The goal of this study is to define the style, work, support and inhibition of the principal's leadership in improving the quality of education and the reality of the quality of education in Cluster II Elementary Schools, Kayuagung District, Ogan Komering Ilir Regency.

\section{METHODS}

Methodology is a primary consideration in the merits of the writing of scientific papers [11]. Based on the issues and priorities, this research uses a qualitative analysis approach that is descriptive of the process used. Moleong argued that qualitative research is intended to explain the phenomena encountered by research participants, such as actions, perception, motivation, action, etc., which are applied holistically and by using explanations expressed in the form of words in a particular context. Normal and using different natural methods [12].

The qualitative descriptive research carried out in this study aims to obtain real data and knowledge about the Principal Leadership Actions in Advancing the Standard of Education in Cluster II Elementary Schools, Kayuagung District, Ogan Komer. The presentation of the data in this study is interactive. In practice, this research begins from recording and summarizing data until it is eventually concluded continuously until the outcome of the research is achieved. Meanwhile, the data base was used for the purpose of sampling and snowball sampling. Sugiyono [13] argued that purposeful sampling is a technique of using data sources with certain factors, such as someone who is considered the most understanding and who knows what we expect so that it makes it easier for researchers to investigate the object or social condition to be examined. Snowball sampling is a data source processing technique where the initial data is small and becomes massive over time. Researchers may add a number of data sources until they feel that they are adequate and that there are no new data additions. This is consistent with Sugiyono's [13] view that "the addition of samples is stopped when the data is saturated and no longer adds new data.

Interactive analysis methods are used to analyze the initial research results, namely three components of the analysis: data reduction, data display and conclusion drawing, which communicate with each other. The verification process always goes back to the data reduction stage, so that triangulation is often implicit in the testing process.
Due to the versatile and transparent nature of qualitative research, while this research uses a set case study approach with research activities based on research goals and clearly defined claims, this research is still open and speculative, since all can be decided later by the actual circumstances at the research site.

The subjects in this study were schools in Cluster II, Kayuagung District, Ogan Koering Ilir Regency, which consisted of 10 elementary schools, which were the samples of this study, there were 4 schools, with a total of 4 school principals, 57 educational staff, 4 administrators and 4 school committees. The data collection techniques used were observation and questionnaire techniques.

The findings of the analysis were evaluated using the observation method and interviews in the descriptive study. The reliability of the instruments in this analysis was derived from the questionnaire and the actual data were completed. The data collected were then evaluated again and some conclusions were drawn from the results of the analysis.

\section{RESULTS AND DISCUSSION}

Principal leadership is a form of dedication on the part of teachers, students and school stakeholders to continuously strengthen and grow their skills and the purpose of professional excellence of running and guiding school resources to work together to achieve common school objectives.

In other words, Principal Leadership is "the ability of a school principal to influence all school components (teachers, students and staff) to be willing to work together, take collective action and act together in achieving the vision, mission and goals of the school".

This study was collected by observation, filling out the requested questionnaire from the school data for the last 5 years. Interviews with Principals, Educators, Boards of Directors and Colleges. From the questionnaire given at the time of observation, equations are obtained from the data of the four schools. The results of the following research will be listed for further details:

The results of the research at SDN 2 Kayuagung, collected data on the position of the workforce on the basis of the number of educational workers in 20152016 as many as 1 school principal, 6 educators/teachers in general studies, 2 teachers in special fields of study: 1 PJOK teacher, 2 PAI teacher, in 2016-2017 the number of staff did not change, in that year the education system used the KTSP curriculum.

In 2017-2018 there was an increase of 1 principal, 10 teaching assistants, 1 PJOK teacher and 2 PAI teachers. In 2018-2019 the number of Class Teachers decreased to 8 Class Teachers, in 2019-2020 the number 
of Class Teachers increased again to 10 Class Teachers, in that year the Education System uses K13, teachers are expected to keep teaching hours 24 hours a week in compliance with the current Regulation.

The state of jobs based on employment status at SDN 2 Kayuagung is $99.64 \%$ civil servants and $0.36 \%$ honorary workers, based on the results of research on labor conditions based on $100 \%$ of Strata 1/S1 education, the test scores obtained in the last 5 years have increased by $25 \%$ per year, the state of the facilities and infrastructure seems to be incomplete, only the master's room, the teacher's room, the school health unit room, the library room, the teacher's toilet, the student's toilet, but it requires additional location because it cannot handle the current number of students exceeding 400. As a result, the student learning process is split into mornings and afternoons, and new spaces do need to be added. Research findings also indicate that many school achievements are derived from the types of painting competitions/competitions, the climate, subdistrict karate, district and national level. Tracing the outcomes of the findings also reveals that $100 \%$ of students graduate each year and continue to study at junior high school/equivalent level.

According to the findings of the research and observations at SDN 1 Muarabaru, in 2015-2016 there were 1 school principal, 22 educators/teachers in general studies, 6 teachers in special fields of study: 3 PJOK teachers, 3 PAI teachers, and in 2016-2017 there was no improvement in the number of teachers in general and special studies. The education system used the KTSP curriculum that year.

In 2017-2019 there was no rise in the number of teachers in general studies or in special fields of study, in 2020 the number of classroom teachers increased again to 1 principal, 22 teachers in general studies, 7 teachers in special studies $3 \mathrm{PJOK}, 4 \mathrm{PAI}$, in the education system uses K13 teachers in compliance with the current law, which is needed to keep teaching hours $24 / 24$.

Conditions of employment based on employment status at SDN 1 Muarabaru $99.56 \%$ of civil servants and $0.44 \%$ of honorary employees, based on the results of studies on the conditions of employment based on education, $100 \%$ Strata $1 / \mathrm{S} 1$, test scores obtained in the last 5 years experiences an increase of $25 \%$ per year, the state of the facilities and the infrastructure as if it is not yet full, there is only the main room, the teacher's room, the school health unit room, the library room, the teacher's toilet, the student's toilet, but it needs local additions because it cannot accommodate the current number of students who exceed 600 , the student learning process is then split into mornings and afternoons, and a further room also needs to be added.
The results of the study also indicate that many school achievements have been made in the form of championships/competitions for two consecutive years winning painting competitions (2016-2017), environmental championships/competitions (2019), karate championships/competitions (2019) painting, poetry (2016), badminton (2017), Science competition (2017), pantomime (2019), pencak silat (2019), karate (2019). At the sub-district, district and national level. Tracing the outcomes of the findings also reveals that $100 \%$ of students graduate each year and continue to study at junior high school/equivalent level.

Research at SDN 16 Kayuagung, obtained the results of research and observations reporting that the state of the workforce based on the number of education staff in 2015-2016 was 1 school principal 6 educators/teachers in general studies, 0 teachers in special fields of study: 0 PJOK teachers, 0 PAI teachers, and in 2016-2017 the number of teachers in general and special subjects did not change. The education system used the KTSP curriculum that year.

In 2017-2020 there was no increase in the number of teachers in general subject areas or in special fields of study, in that year the education system using K13 teachers in compliance with the current regulation is expected to hold 24 hours of teaching per week. Labor situation based on employment status in SDN 16 Kayuagung $100 \%$ Civil Servants, based on results of labor condition research based on $100 \%$ of Strata 1/S1 education, test scores achieved in the last 5 years have increased by $25 \%$ per year, the condition of facilities and infrastructure seems to be as though it is not yet complete. There is the master's space, the teacher's room, the school health unit room, the library room, the teacher's toilet, the student's toilet, however there is a need for additional local additions, the classrooms are adequate since the current number of students is 160 , so the student learning process begins in the morning.

The results of the study also show that there are many school achievements in the types of competitions: poetry reading competition (2017), long distance running race (2018) competition for the processing of used goods (2019) at the sub-district, district and national level. Tracing the outcomes of the findings also reveals that $100 \%$ of students graduate each year and continue to study at junior high school/equivalent level.

The results of the research at SDN 1 Ranjung Rancing show that, in 2015-2016, there were 1 school principal, 6 educators/teachers in general studies, 0 teachers in special fields of study: 0 PJOK teachers, 0 PAI teachers, and in 2016-2017 there was no improvement in the number of teachers in general and special studies. The education system used the KTSP curriculum that year. In 2017-2020 there was no increase in the number of teachers in general studies or of teachers in special fields of study, in that year the 
education system using K13 teachers in accordance with the current regulation is expected to last 24 hours a week.

The state of jobs based on the employment status of SDN 1 Tanjungranceng is $100 \%$ civil servants, based on the results of research on labor conditions based on $100 \%$ of Strata 1/S1 education, the test scores obtained in the last 5 years have increased by $25 \%$ per year, the conditions of the facilities and the infrastructure tend to be incomplete, only $\mathrm{pr}$ are available. Tracing the outcomes of the findings also reveals that $100 \%$ of students graduate each year and continue to study at junior high school/equivalent level.

The results of the interviews conducted with school principals, educators, administrators and school boards in the SDN cluster II, Kayuagung Subdistrict, Ogan Komering Ilir District, the appointed school principal met the general and unique criteria set out in the new rules of assignment as primary school year 2018 on the basis of Permendikbud number 6 of 2018. Democratic, educators, managers, executives, supervisors and supervisors. Principals serve as leaders who offer visions, missions and create a sense of pride and confidence and trust in their subordinates, and apply intellectual stimulation to meeting and resolving problems at school.

\section{CONCLUSION}

These findings are based on the results of the research and questionnaires collected in 4 schools at the time of the report.1 The number of teachers at SD 2 Kayuangung and SDN 1 Muarabaru is obviously not appropriate for teachers or teachers in the field of study and it is necessary to send a request for a new teacher to the Ogan Komering District Education Office. Ilir remembered that the number of students had reached 400-600, 2. SDN 16 Kayuagung and SDN 1 Tanjungrancing also required the addition of PAI and PJOK teachers only. There is still a great deal of lack of facilities and schools in the SDN cluster II, Kayuangung district, including local learning, multimedia space, computer room, worship room, administration room, sports room, multipurpose room, lobby room and meeting room, and plans for the addition of a new building to the Ogan Komering Ilir District Education Office can be made.

\section{ACKNOWLEDGMENTS}

Thank you very much to the Principal and Teacher Board of SDN 1 Lubukdalam,Kecamatan Kayuagung OKI, South of Sumatra. It was also forwarded to the Chancellor, Postgraduate Director, Head of Education Management Study Program, Advisor I, Supervisor II and all postgraduate lecturers at PGRI Palembang University. Also, for all fellow graduate students of
PGRI Palembang University. Thank you for helping to complete this journal, which is the result of the preparation of the thesis as a prerequisite for the final report. Please criticize and recommend to develop this journal.

\section{REFERENCES}

[1] Handayani, D. O., Kristiawan, M., \& Destiniar. (2020). Education and Training for Strengthening Principal to Effective Schools. International Journal of Progressive Sciences and Technologies (IJPSAT), 22(1), 321-326.

[2] Rahmadoni, J. (2018). Isu Global Manajemen Pembiayaan Pendidikan di SD Indonesian Creative School Pekanbaru. Jurnal Manajemen, Kepemimpinan dan Supervisi Pendidikan 3(2), Juli-Desember 2018.

[3] Asvio, N., Yamin, M., \& Risnita. (2019). Influence of Leadership Style, Emotional Intelligence and Job Satisfaction toward Organizational Commitment (Survey at SMA Muhammadiyah South Sumatera). International Journal of Scientific \& Technology Research 8 (8).

[4] Sarbini., Kristiawan, M., \& Wardiah, D. (2020). Supervisor's Performance for the Quality of Education. International Journal of Progressive Sciences and Technologies (IJPSAT), 20(1), 255262.

[5] Mulyasa. (2006). Menjadi Kepala Sekolah Profesional [Become a Professional School Principal]. Bandung: PT Remaja Rosdakarya.

[6] Danim, S. (2015). Visi Baru Manajemen Sekolah: Dari Unit Birokrasi ke Lembaga Akademik. Cetakan ke Lima [New Vision of School Management: From the Bureaucratic Unit to Academic Institutions Fifth Printing]. Jakarta: Bumi Aksara.

[7] Wahjosumidjo (2011). Kepemimpinan Kepala Sekolah [Principal Leadership]. Jakarta: PT. Raja Grafindo Persada

[8] Maseleno, A., Ayshwary, B., Ivanova, T. N., Hashim, W., Nguyen, P. T., Shankar, K., Kristiawan, M., Huda, M. (2019). General Theoretical and Philosophical Aspects of Modern Education. Aspectos Teóricos y Filosóficos Generales de la Educación Moderna. Revista San Gregorio 2019, No. 32 Special Issues August.

[9] Triatna, C. (2015). Pengembangan Manajemen Sekolah [School Management Development]. Bandung: PT Remaja Rosdakarya. 
[10] PP Nomor 19 Tahun 2005 tantang Standar Nasional Pendidikan [National Education Standards]. Pasal 38 Ayat 2

[11] Muttaqin, K., \& Rahmadoni, J. (2020). Analysis and Design of File Security System AES (Advanced Encryption Standard) Cryptography Based. Journal of Applied Engineering and Technological Science (JAETS), 1(2), 113-123. https://doi.org/10.37385/jaets.v1i2.78

[12] Moleong, L. J. (2012). Metodologi Penelitian Kualitatif Edisi Revisi [Qualitative Research Methodology. Revised Edition]. Bandung: PT. Remaja Rosdakarya.

[13] Sugiyono. (2009). Metode Penelitian Pendidikan Pendekatan Kuantitatif, Kualitatif, dan $R \& D$ [Educational Research Methods with Quantitative Approaches, Qualitative, and $R \& D$ ]. Bandung: CV Alfabeta. 